\title{
KEDUDUKAN PERJANJIAN PERKAWINAN \\ MENURUT HUKUM ISLAM
}

\section{Oleh :}

Hj. Dra. Lilies Anisah, SH.,MH

\author{
(Dosen Fakultas Hukum Universitas Muhammadiyah Palembang) \\ Email : lilies_anisah@um-palembang.ac.id
}

\begin{abstract}
ABSTRAK
Secara umum perjanjian perkawinan berisi tentang pengaturan harta kekayaan calon suami istri. Sedangkan tujuannya untuk mengatur akibat-akibat perkawinan yang menyangkut harta kekayaan.Di dalam Hukum Islam perjanjian perkawinan ini baru sah apabila dibuat sebelum atau pada saat perkawinan, sesuai dengan ketentuan Pasal 47 ayat (1) KHI, yaitu : "Pada waktu atau sebelum perkawinan dilangsungkan kedua calon mempelai dapat membuat perjanjian tertulis yang disahkan Pegawai Pencatat Nikah mengenai kedudukan harta dalam perkawinan" Adalah lebih baik jikalau perjanjian perkawinan itu dilakukan lebih dahulu sebelum perkawinan, ditandatangani dan dibacakan atau dilafazkan sesudah perkawinan.
\end{abstract}

Kata Kunci :Perjanjian Perkawinan,Hukum Islam

\begin{abstract}
In general, the marriage agreement contains the arrangement of the assets of the prospective husband and wife. Meanwhile, the aim is to regulate the consequences of marriage relating to assets. In Islamic law this marriage agreement is only valid if it is made before or at the time of marriage, in accordance with the provisions of Article 47 paragraph (1) KHI, namely: "At the time or before the marriage takes place. The two prospective brides can make a written agreement that is legalized by the Marriage Registrar regarding the position of assets in the marriage. It is better if the marriage agreement is made before marriage, signed and read or pronounced after the marriage.
\end{abstract}

Keywords: Marriage Agreement, Islamic Law

\section{A. Latar Belakang}

Perkawinan merupakan institusi yang sangat penting dalam masyarakat.Eksistensi institusi adalah melegalkan hubungan hukum antara seorang laki-laki dan perempuan. ${ }^{1}$ Perkawinan dapat dikatakan ibadah jika dilakukan dengan niat yang baik, niat itu untuk

${ }^{1}$ Salim HS,SH Pengantar Hukum Perdata,Sinar Grafika,Jakarta,2013,hlm.61 
menjalankan syariat Allah SWT. Perkawinan yang demikian akan mendapat ridhaNya dan perkawinannya akan berakhir dengan sakinah, mawaddah, warahmah.

Hal ini dapat dilihat dalam rumusan pengertian perkawinan pada Pasal 1 Undangundang Nomor 1 Tahun 1974 tentang Perkawinan, menyebutkan bahwa: "Perkawinan adalah ikatan lahir batin antara seorang pria sebagai suami istri dengan tujuan mewujudkan keluarga (rumah tangga) yang bahagia dan kekal berdasarkan Ketuhanan yang Maha Esa”.

Definisi perkawinan menurut Wirjono Prodjodikoro adalah : "Hidup bersama dari seorang laki-laki dan seorang perempuan $\quad$ yang memenuhi syarat-syarat tertentu”.2

Berdasarkan pengertian di atas sudah jelas, bahwa perkawinan dilangsungkan bukan untuk sementara atau untuk waktu tertentu, tetapi untuk seumur hidup atau untuk selama-lamanya. Oleh karena itu diharapkan agar pemutusan ikatan suami-istri itu tidak terjadi kecuali karena kematian. perceraian hanyalah merupakan jalan terakhr, setelah usaha-usaha lain memang benar-benar tidak dapat memberikan solusinya.

Alasan-alasan yang dapat dijadikan dasar untuk melakukan perceraian menurut Pasal 19 Undang-Undang Nomor 1 Tahun 1974 tentang Perkawinan adalah sebagai berikut :

a. Salah satu pihak berbuat zina atau menjadi pemabuk, pemadat, penjudi dan lain sebagainya yang sukar disembuhkan;

b. Salah satu pihak meninggalkan yang lain selama 2 (dua) tahun berturut-turut tanpa izin pihak yang lain dan tanpa alasan yang sah atau karena hal lain di luar kemampuannya;

c. Salah satu pihak mendapat hukuman penjara 5 (lima) tahun atau hukuman yang lebih berat setelah perkawinan berlangsung;

d. Salah satu pihak melakukan kekejaman atau penganiayaan berat yang membahayakan terhadap pihak yang lain;

e. Salah satu pihak mendapat cacat badan atau penyakit yang mengakibatkan tidak dapat menjalankan kewajibannya sebagai suami/istri ;

f. Antara suami dan istri terus menerus terjadi perselisihan dan pertengkaran dan tidak ada harapan akan hidup rukun dalam rumah tangga.

${ }^{2}$ Wirjono Prodjodikoro, Hukum Perkawinan di Indonesia, Bandung: Sumur Bandung, 1981, hlm. 7. 
Salah satu akibat hukum yang ditimbulkan dari putusnya perkawinan karena perceraian adalah terkait masalah harta benda perkawinan khususnya terhadap harta bersama yang di peroleh dalam perkawinan tersebut, keinginan orang untuk membuat perjanjian perkawinan.

Perjanjian Kawin diatur dalam Pasal 35, yang menentukan :

1. Harta benda yang diperoleh selama perkawinan menjadi harta bersama.

2. Harta bawaan dari masing-masing suami-isteri dan harta benda yang diperoleh masing-masing sebagai hadiah atau warisan adalah di bawah pengawasan masingmasing sepanjang para pihak tidak menentukan lain.

Secara umum perjanjian perkawinan berisi tentang pengaturan harta kekayaan calon suami istri. Sedangkan tujuannya untuk mengatur akibat-akibat perkawinan yang menyangkut harta kekayaan. ${ }^{3}$

Di dalam Hukum Islam perjanjian perkawinan ini baru sah apabila dibuat sebelum atau pada saat perkawinan, sesuai dengan ketentuan Pasal 47 ayat (1) KHI, yaitu : "Pada waktu atau sebelum perkawinan dilangsungkan kedua calon mempelai dapat membuat perjanjian tertulis yang disahkan Pegawai Pencatat Nikah mengenai kedudukan harta dalam perkawinan" Adalah lebih baik jikalau perjanjian perkawinan itu dilakukan lebih dahulu sebelum perkawinan, ditandatangani dan dibacakan atau dilafazkan sesudah perkawinan.

Perjanjian perkawinan yang diatur dalam Pasal 29 Undang-Undang Perkawinan Nomor 1 Tahun 1974 bukan hanya mengatur masalah harta benda dan akibat perkawinan saja melainkan juga meliputi hak-hak/kewajiban yang harus dipenuhi oleh kedua belah pihak sepanjang perjanjian itu tidak bertentangan dengan batas-batas hukum, agama dan kesusilaan. Di samping itu dalam penjelasan Pasal 29 Undang-undang Perkawinan

\footnotetext{
${ }^{3}$ Happy Susanto, Pembagian Harta Gono gini Saat Terjadi Perceraian, Cet.Ke-2, Visimedia, Jakarta: 2008 , hlm.. 78
} 
Nomor 1 Tahun 1974, ditegaskan bahwa "perjanjian” yang dimaksud dalam Pasal 29 tersebut tidak termasuk ta'lik talak. Sedang di dalam Hukum Islam mengenai perjanjian perkawinan tidak diatur secara khusus seperti halnya perjanjian perkawinan yang terdapat di dalam Undang-undang Perkawinan Nomor 1 Tahun 1974. Hal tersebut kiranya perlu diteliti lebih lanjut mengenai perjanjian kawin menurut Undang-undang Perkawinan Nomor 1 Tahun 1974 dengan Hukum Islam

\section{B. Permasalahan}

Adapun permasalahan dalam tulisan ini adalah bagaimana kedudukan perjanjian perkawinan menurut Hukum Islam?

\section{Pembahasan}

Perjanjian perkawinan menurut Undang-undang Perkawinan No. 1 Tahun 1974 merupakan pernyataan kehendak dari kedua belah pihak yang membuatnya, sedangkan perjanjian perkawinan atau ta'lik talak dalam Kompilasi Hukum Islam merupakan pernyataan kehendak secara sepihak.

Perjanjian perkawinan dalam Undang-undang Perkawinan No. 1 Tahun 1974 dapat dibuat sebelum atau pada saat perkawinan dilangsungkan dan dapat dirubah apabila telah memenuhi persyaratan.Terdapat dua bentuk perjanjian perkawinan yang dimungkinkan dalam Islam, yaitu taklik talak dan perjanjian lain yang tidak bertentangan dengan hukum Islam.

\section{Taklik talak}

Menurut Pasal 1 huruf e KHI, yang dimaksud dengan:

Taklik talak ialah perjanjian yang diucapkan calon mempelai pria setelah akad nikah yang dicantumkan dalam akta nikah berupa janji talak yang digantungkan kepada suatu keadaan tertentu yang mungkin terjadi di masa yang akan datang. Dalam hal taklik talak, terdapat beberapa hal yang perlu diperhatikan, di antaranya: 
a. Isi taklik talak tidak boleh bertentangan dengan hukum Islam. ${ }^{4}$

b. Apabila keadaan yang terdapat dalam taklik talak terjadi, maka bukan berarti talak jatuh dengan sendirinya. Istri harus mengajukan ke Pengadilan Agama untuk menjatuhkan talak tersebut. ${ }^{5}$

c. Perjanjian taklik talak bukan hal yang wajib diadakan. ${ }^{6}$

d. Apabila suami telah membuat taklik talak, maka taklik talak tersebut tidak dapat dicabut kembali. $^{7}$

\section{Perjanjian lain yang tidak bertentangan dengan hukum Islam}

Pasal 47 ayat (1) KHI mendeskripsikan frasa 'perjanjian lain yang tidak bertentangan dengan hukum Islam' sebagai berikut: Pada waktu atau sebelum perkawinan dilangsungkan, kedua calon mempelai dapat membuat perjanjian tertulis yang disahkan Pegawai Pencatat Nikah mengenai kedudukan harta dalam perkawinan.

Adapun isi perjanjian perkawinan dapat berupa:

\section{Percampuran harta pribadi}

Hal ini sesuai dengan ketentuan dalam Pasal 47 ayat (1) dan (2) KHI yang mengatur sebagai berikut:

a. Pada waktu atau sebelum perkawinan dilangsungkan kedua calon mempelai dapat membuat perjanjian tertulis yang disahkan Pegawai Pencatat Nikah mengenai kedudukan harta dalam perkawinan.

b. Perjanjian tersebut dalam ayat (1) dapat meliputi percampuran harta pribadi dan pemisahan harta pencaharian masing-masing sepanjang hal itu tidak bertentangan dengan Islam.

Pada dasarnya, perkawinan tidak menimbulkan adanya percampuran harta

\footnotetext{
${ }^{4}$ Pasal 46 ayat (1) KHI

${ }^{5}$ Pasal 46 ayat (2) KHI

${ }^{6}$ Pasal 46 ayat (3) KHI

${ }^{7}$ Pasal 46 ayat (3) KHI
} 
antara suami-istri karena harta di dalam hukum Islam bersifat individual.Hal ini sebagaimana yang diatur dalam Pasal 86 ayat (1) KHI:Pada dasarnya tidak ada percampuran antara harta suami dan harta istri karena perkawinan.

Namun, apabila kedua pihak ingin melakukan pencampuran harta pribadi maka hal tersebut dibolehkan.Dengan catatan, apa yang diatur di dalam perjanjian tersebut tidak bertentangan dengan hukum Islam.

\section{Pemisahan harta pencaharian}

Merujuk pada Pasal 47 ayat (2) di atas, kedua pihak juga dapat mengatur mengenai pemisahan harta pencaharian masing-masing selama dalam ikatan perkawinan.Menurut Sayuti Thalib dalam buku Hukum Kekeluargaan Indonesia, yang dimaksud dengan harta pencaharian adalah harta yang diperoleh oleh suami istri setelah mereka berada dalam perkawinan karena usaha, baik usaha mereka berdua atau usaha salah seorang dari mereka. ${ }^{8}$

Dalam hal pemisahan harta pencaharian, isi perjanjian tersebut tidak boleh menghilangkan kewajiban suami untuk memenuhi kebutuhan rumah tangga. Hal ini sebagaimana yang diatur dalam Pasal 48 ayat (1) KHI: Apabila dibuat perjanjian perkawinan mengenai pemisahan harta bersama atau harta syarikat, maka perjanjian tersebut tidak boleh menghilangkan kewajiban suami untuk memenuhi kebutuhan rumah tangga.

\section{Kewenangan masing-masing untuk mengadakan ikatan hipotik atas harta} pribadi dan harta bersama

Selain itu, kedua pihak juga dapat mengadakan ikatan hipotik atas harta pribadi dan harta bersama.Hal ini sesuai dengan ketentuan dalam Pasal 47 ayat (3) KHI.Di samping ketentuan dalam ayat (1) dan (2) di atas, boleh juga isi perjanjian

\footnotetext{
${ }^{8}$ Sayuti Thalib , Hukum Kekeluargaan Indonesia, UI Press, Jakarta, ,hlm.83
} 
itu menetapkan kewenangan masing-masing untuk mengadakan ikatan hipotek atas harta pribadi dan harta bersama atau harta syarikat.

Selain mengatur mengenai harta, perjanjian perkawinan juga dapat mengatur hal-hal tambahan seperti hak dan kewajiban suami istri, pengaturan poligami, hak asuh anak, dan lain-lain.

\section{Penutup}

\section{Kesimpulan}

Perjanjian perkawinan menurut Undang-undang Perkawinan No. 1 Tahun 1974 merupakan pernyataan kehendak dari kedua belah pihak yang membuatnya, sedangkan perjanjian perkawinan atau ta'lik talak dalam Kompilasi Hukum Islam merupakan pernyataan kehendak secara sepihak. Perjanjian perkawinan dalam Undang-undang Perkawinan No. 1 Tahun 1974 dapat dibuat sebelum atau pada saat perkawinan dilangsungkan dan dapat dirubah apabila telah memenuhi persyaratan.Terdapat dua bentuk perjanjian perkawinan yang dimungkinkan dalam Islam, yaitu taklik talak dan perjanjian lain yang tidak bertentangan dengan hukum Islam

\section{Saran-Saran}

a. Sebaiknya para pihak yang hendak membuat perjanjian perkawinan yang dibuat setelah perkawinan berlangsungmengatur waktu mulai berlakunya perjanjian perkawinan, yakni sejak perjanjian tersebut dibuat, sehingga perjanjian tersebut tidak berlaku surut.

b. .Sebaiknya para pihak membuat perjanjian perkawinan di hadapan notaris agar para pihak dapat mendapatkan penyuluhan hukum tentang kondisi terbaik bagi harta kekayaan mereka. 


\section{DAFTAR PUSTAKA}

Happy Susanto, Pembagian Harta Gono gini Saat Terjadi Perceraian, Cet.Ke-2, Visimedia, Jakarta: 2008

Salim HS,SH Pengantar Hukum Perdata,Sinar Grafika,Jakarta,2013

Sayuti Thalib , Hukum Kekeluargaan Indonesia, UI Press, Jakarta

Wirjono Prodjodikoro, Hukum Perkawinan di Indonesia, Bandung: Sumur Bandung, 1981 